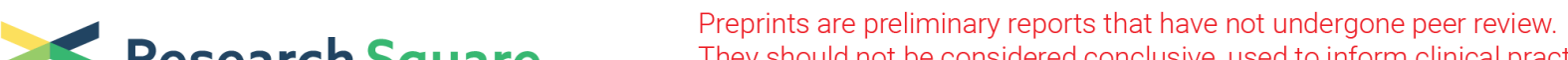 Research Square They should not be considered conclusive, used to inform clinical practice, or referenced by the media as validated information. \\ Effects of Electron Donors and Acceptors on $\mathrm{Cr}(\mathrm{VI})$ Removal in Biotic $\mathrm{Fe}^{0}$ Columns Preloaded with Microorganisms
}

\section{Weiquan Li}

South China University of Technology School of Environment and Energy

\section{Mingxi Li}

South China University of Technology School of Environment and Energy

Weizhao Yin

Jinan University School of Environment

\section{Sihao Lv}

Dongguan University of Technology

\section{Jiawei Zhong}

South China University of Technology School of Environment and Energy

\section{Ping Li}

South China University of Technology School of Environment and Energy

\section{Hong Deng}

South China University of Technology School of Environment and Energy

Jinhua Wu ( $\nabla$ jinhuawu@scut.edu.cn )

South China University of Technology School of Environment and Energy https://orcid.org/0000-00018139-2234

\section{Research Article}

Keywords: Zero-valent iron, Secondary mineral, Chromium, Electron donor, Electron acceptor

Posted Date: January 25th, 2022

DOI: https://doi.org/10.21203/rs.3.rs-1191375/v1

License: (9) This work is licensed under a Creative Commons Attribution 4.0 International License. Read Full License 


\section{Abstract}

The removal of $\mathrm{Cr}(\mathrm{VI})$ from groundwater by zero-valent iron $\left(\mathrm{Fe}^{0}\right)$ and microorganisms under different nutrients and electron-accepting conditions was investigated using continuously-flowed column reactors with an abiotic $\mathrm{Fe}^{0}$ column as the control. Both abiotic and biotic $\mathrm{Fe}^{0}$ columns were operated at low and relatively high concentrations of organic substrates (sodium acetate and humic acid) and electron acceptors (nitrate and sulfate). Sodium acetate and humic acid were found to be effective substrates for the biotic $\mathrm{Fe}^{0}$ system to remove $\mathrm{Cr}(\mathrm{VI})$ since microorganisms were able to gain extra reducing capacity from two nutrients and simultaneously avoid the passivation effect of humic acids on $\mathrm{Fe}^{0}$ by metabolizing them. For nitrate and sulfate, varied influences were observed in the biotic $\mathrm{Fe}^{0}$ system. The former showed apparent inhibition on $\mathrm{Cr}(\mathrm{VI})$ removal as it competed with $\mathrm{Cr}(\mathrm{VI})$ for electrons, and the inhibition became more severe while nitrate concentrations increased. Differently, highly reactive minerals such as green rusts and iron sulfide could be generated on the biotic $\mathrm{Fe}^{0}$ surface under sulfate-reducing conditions. They significantly enhanced $\mathrm{Cr}(\mathrm{VI})$ removal by providing more adsorptive and reductive sites. Overall, though the biotic $\mathrm{Fe}^{0}$ column exhibited a longer life-span and higher $\mathrm{Cr}(\mathrm{VI})$ removal capacity than the abiotic $\mathrm{Fe}^{0}$ column, the effects of organic substrates and electron acceptors should still be taken into account when applying biotic $\mathrm{Fe}^{0}$ systems for $\mathrm{Cr}(\mathrm{VI})$-contaminated groundwater remediation.

\section{Introduction}

Chromium is an important metal and finds a variety of uses in industries such as metallurgy, leather tanning, electroplating and pigment productions (GracePavithra et al. 2019). As a result of improper disposal and accidental leakages, chromium is released to soil and aquifer, causing adverse influences to most living organisms. Naturally, chromium mainly exists in $\mathrm{Cr}(\mathrm{VI})$ and $\mathrm{Cr}(\mathrm{III})$ oxidative forms. The latter species have a low solubility in water and are less mobile. In contrast, because of its oxyanion form, the $\mathrm{Cr}(\mathrm{VI})$ is weakly adsorbed onto inorganic surfaces and has significant mobility in groundwater (Richard \&Bourg 1991). Moreover, $\mathrm{Cr}(\mathrm{VI})$ is considered to be a highly toxic substance that can cause human cancer by inhalation or oral exposure (Zhitkovich 2011). Therefore, $\mathrm{Cr}(\mathrm{VI})$ has been listed as a hazardous contaminant by many countries, and effective methods are required to remediate $\mathrm{Cr}(\mathrm{VI})$-contaminated groundwaters.

To date, due to the low redox potential $\left(E^{0}=-0.44 \mathrm{~V}\right)$ and environmental-friendly properties of metallic iron, $\mathrm{Fe}^{0}$-based permeable reactive barriers (PRBs) have been widely investigated in laboratories or fieldscale sites for $\mathrm{Cr}(\mathrm{VI})$-containing groundwater treatment (Cao et al. 2022, Wang et al. 2022). Many studies (Gheju 2011, Wilkin et al. 2005) reported that $\mathrm{Cr}(\mathrm{VI})$ can be adsorbed on $\mathrm{Fe}^{0}$ surface and reduced to $\mathrm{Cr}$ (III) by accepting electrons $\mathrm{Fe}^{0} / \mathrm{Fe}^{2+}$ while $\mathrm{Fe}^{0}$ is finally oxidized to $\mathrm{Fe}^{3+}$. Meanwhile, as iron corrosion continuously progresses, $\mathrm{Cr}(\mathrm{VI})$ and resulted $\mathrm{Cr}(\mathrm{III})$ can be encapsulated or immobilized in iron oxides/hydroxides, which considerably diminishes the exposure or availability of chromium. In addition to chemical reduction and physical elimination, $\mathrm{H}_{2}$ generated in the anoxic iron corrosion process can serve as a potential electron donor for some facultative hydrogen-consuming bacteria to metabolize and 
simultaneously induce a coupled abiotic and biotic effect in $\mathrm{Fe}^{0}-\mathrm{H}_{2} \mathrm{O}$ systems (Dinh et al. 2004). For example, these microorganisms can directly reduce $\mathrm{Cr}(\mathrm{VI})$ by utilizing $\mathrm{H}_{2}$ (Battaglia-Brunet et al. 2002, Chung et al. 2006). Besides, some specific bacteria, like iron-reducing bacteria (IRB), can increase the availability of reactive sites on $\mathrm{Fe}^{0}$ surface by cleaning up passive precipitates and generating highly reactive minerals (e.g., green rust and magnetite) (Yang et al. 2017), which can promote the removal performance as well as the utilization and life-span of $\mathrm{Fe}^{0}$-based PRBs. Hence, the combined use of $\mathrm{Fe}^{0}$ and microorganisms is of great potential for in-situ remediation of $\mathrm{Cr}(\mathrm{VI})$-contaminated groundwater as it may be more effective and long-acting (Yin et al. 2015).

Recently, this modified biotic $\mathrm{Fe}^{0}$ system has been studied for the removal of nitrate, explosive, chlorohydrocarbon and chromium, and its superior removal performance and economical operation condition has made it become an ideal pollution control method (Niedzwiecka \&Finneran 2015, Oh et al. 2001, Shin \&Cha 2008, Zhong et al. 2017). These studies investigated the reaction progress between $\mathrm{Fe}^{0}$ and microorganisms, and their synergistic mechanism in removing pollutants. Additionally, the effects of operational parameters and hydraulic conditions such as iron size, iron dosage, density of microorganisms, influent $\mathrm{pH}$, flow rate of fluid and initial concentration of contaminants have also been well studied (Yin et al. 2017, Yin et al. 2016). However, little attention has been paid to the effects of coexisting matters such as natural organic matters (NOMs) and common inorganic anions on $\mathrm{Cr}(\mathrm{VI})$ removal in the biotic $\mathrm{Fe}^{0}$ system, while the groundwater usually consists of various organic or inorganic components (Fitts 2002). Generally, the coexisting matters may affect the reactivity of $\mathrm{Fe}^{0}$ itself and alter the growth and metabolism properties of microorganisms and their dominant communities. On the one hand, NOMs can deposit on iron surfaces and possibly diminish reactive sites in the $\mathrm{Fe}^{0}-\mathrm{H}_{2} \mathrm{O}$ system (Dries et al. 2005, Liu et al. 2009b). On the other hand, NOMs can provide microorganisms with additional electrons and extra reducing capacity to promote their activity and the synergistic interaction with $\mathrm{Fe}^{0}$ (Wu et al. 2013). Besides, the existence of some inorganic anions may serve as electron acceptors to compete with $\mathrm{Cr}(\mathrm{VI})$ for electrons and therefore misdirect the desired electron flow, which is unfavorable for $\mathrm{Cr}(\mathrm{VI})$ removal (Gu et al. 1999). Thus, it is necessary to figure out the effect of NOMs and inorganic anions and their active mechanisms on $\mathrm{Cr}(\mathrm{VI})$ removal by the biotic $\mathrm{Fe}^{0}$ system, and which conclusion can provide a reference for the synergistic approach in practical application.

The present work was accordingly carried out to investigate the $\mathrm{Cr}(\mathrm{VI})$ removal capacity of the biotic $\mathrm{Fe}^{0}$ system under different organic and electron-accepting conditions. In this study, continuously-flowed columns were used to simulate the $\mathrm{Fe}^{0}$-based PRBs. Sodium acetate (SA) and humic acid (HA) were selected as typical NOMs. Nitrate $\left(\mathrm{NO}_{3}{ }^{-}\right)$and sulfate $\left(\mathrm{SO}_{4}{ }^{2-}\right)$ were chosen as common inorganic anions or electron acceptors in groundwater to explore their effects on $\mathrm{Cr}(\mathrm{VI})$ removal in the biotic $\mathrm{Fe}^{0}$ system.

\section{Materials And Methods}

\subsection{Materials}


Granular iron $(0.45 \mathrm{~mm})$ was purchased from Shanghai Aladdin Company and applied as experimental supplies without additional treatment. Quartz sand (0.5-1 mm) obtained from Guangdong Huaneng Company was used for dispersing the iron particles and adjusting the porosity of column reactors. Before filling into columns, the sand was washed with $1 \mathrm{M} \mathrm{HCl}$ for $24 \mathrm{~h}$, rinsed to neutral with deionized water, air-dried and autoclaved.

Sludge obtained from a municipal sewage plant was inoculated and cultivated in an anaerobic bioreactor $(5 \mathrm{~L})$ for the acclimation of $\mathrm{Cr}(\mathrm{VI})$-reducing bacteria. The cultivation process was similar to our previous study (Zhong et al. 2017). In the start-up phase, the suspended solids (SS) and granular iron dosage were 5 and $10 \mathrm{~g} \mathrm{~L}^{-1}$, respectively. The feeding $\mathrm{Cr}(\mathrm{VI})$ concentration was $10 \mathrm{mg} \mathrm{L}^{-1}$ and a medium comprised of nutrient and trace metals was fed simultaneously ( $\mathrm{mg} \mathrm{L}^{-1}$ in deionized and deoxygenated water): glucose (1000), $\mathrm{NH}_{4} \mathrm{Cl}$ (300), $\mathrm{K}_{2} \mathrm{HPO}_{4}$ (175), $\mathrm{MgCl}_{2}$ (75), $\mathrm{CaCl}_{2}$ (100), $\mathrm{NaHCO}_{3}$ (1000), $\mathrm{CoCl}_{2} \cdot 5 \mathrm{H}_{2} \mathrm{O}$ (0.0001), $\mathrm{CuCl}_{2} \cdot 2 \mathrm{H}_{2} \mathrm{O}(0.0001), \mathrm{MnCl}_{2} \cdot 4 \mathrm{H}_{2} \mathrm{O}(0.0001), \mathrm{NiCl}_{2} \cdot 6 \mathrm{H}_{2} \mathrm{O}(0.0001), \mathrm{NH}_{4} \mathrm{MO}_{3}(0.0001)$ and $\mathrm{ZnSO}_{4}(0.0001)$. The hydraulic retention time was kept at $1 \mathrm{~d}$ and the effluent $\mathrm{Cr}(\mathrm{VI})$ concentration was measured every 2 d. After 6 months of acclimation, the $\mathrm{Cr}(\mathrm{VI})$ removal efficiency was over $90 \%$. Then this mixed anaerobic culture was added directly to the column reactors without further acclimation.

Synthetic $\mathrm{Cr}(\mathrm{VI})$-contaminated groundwater was prepared $\left(\mathrm{mg} \mathrm{L}^{-1}\right)$ by dissolving $\mathrm{K}_{2} \mathrm{Cr}_{2} \mathrm{O}_{7}(10$ as $\mathrm{Cr}(\mathrm{VI}))$, $\mathrm{K}_{2} \mathrm{HPO}_{4}(25), \mathrm{NH}_{4} \mathrm{Cl}(45), \mathrm{CaCl}_{2}(50), \mathrm{MgCl}_{4}$ (75), $\mathrm{NaHCO}_{3}$ (1000) and the aforementioned trace metals into autoclaved, deionized and deoxygenated water based on Chinese National Standard of Groundwater (GB/T14848-93). The initial $\mathrm{pH}$ value was adjusted to $7.0 \pm 0.1$ using $0.1 \mathrm{M} \mathrm{HCl}$ or $0.1 \mathrm{M} \mathrm{NaOH}$ and the initial oxidation-reduction potential (ORP) value was measured to be $210 \pm 10 \mathrm{mV}$. All chemicals used in this study were of analytical reagent grade.

\subsection{Column study}

The column setup and solid phase sampling processes were conducted in an anaerobic chamber $\left(\mathrm{N}_{2}: \mathrm{H}_{2}=95: 5\right)$ during the experiment. Four PVC columns ( $2 \mathrm{~cm}$ internal diameter $\times 25 \mathrm{~cm}$ length) were used to mimic $\mathrm{Fe}^{0}$-based PRBs. The columns were equipped with five lateral sampling ports at a distance of 5 , 10, 15, 20 and $25 \mathrm{~cm}$ from the inlet. They were mainly divided into four groups: (1) the abiotic $\mathrm{Fe}^{0}$ column, (2) the biotic Fe ${ }^{0}$ column, (3) the sand column, (4) the cell column. Among them, the abiotic $\mathrm{Fe}^{0}$ column was carefully packed with sand and iron particles through a paper slot to obtain a wholly mixed distribution. Likewise, the biotic $\mathrm{Fe}^{0}$ column was prepared in the same way but additionally added with the acclimated culture through a burette while packing sand and iron particles. The other two columns were used as controls: one was filled exclusively with sand and the other was filled with the mixture of sand and the acclimated culture. After packing, the columns were sealed by rubber plugs assembled with redox potential probes for real-time measurement of ORP (oxidation/reduction potential) values. All columns and materials were autoclaved for sterilization before packing. In this study, low iron dosage with a bulk density of $0.358 \mathrm{~g} \mathrm{~cm}^{-3}$ (iron/sand ratio of 3:10 (w:w)) was adopted, and the initial biomass concentration in the biotic columns was $400 \mathrm{mg} \mathrm{L}^{-1}$ as volatile suspended solids (VSS). The porosities of 
all columns were $0.48 \pm 0.02$, and the pore volumes (PVs) were $40 \pm 1.7 \mathrm{~cm}^{3}$. The synthetic $\mathrm{Cr}(\mathrm{VI})$ contaminated groundwater was fed continuously into the columns up-flow by peristaltic pumps at a flow rate of $0.33 \mathrm{~mL} \mathrm{~min}^{-1}$, resulting in a seepage velocity of $569 \mathrm{~m}$ year $^{-1}$ and the required time for $1 \mathrm{PV}$ was $2 \mathrm{~h}$. For the effect of NOMs, 10 and $100 \mathrm{mg} \mathrm{L}^{-1}$ as COD were chosen as low to high values in the experiment of $\mathrm{SA}$, while 5 and $50 \mathrm{mg} \mathrm{L}^{-1}$ as COD were selected in the effect of HA. For the effect of electron acceptors, 5 and $50 \mathrm{mg} \mathrm{L}^{-1} \mathrm{NO}_{3}{ }^{-}-\mathrm{N}$ were chosen as low to high values in the effect of nitrate whereas the concentration of sulfate varied from 100 to $800 \mathrm{mg} \mathrm{L}^{-1} \mathrm{SO}_{4}{ }^{2-}$. Besides, no $\mathrm{NH}_{4} \mathrm{Cl}$ was added to the solution at the nitrate effect experiment. The column study was operated at $25^{\circ} \mathrm{C}$.

Water samples were periodically collected from the side sampling ports. Before collecting, about $1 \mathrm{~mL}$ of stagnant water in the port was discarded. Then $5 \mathrm{~mL}$ of the solution from each port was collected and filtered through a $0.45 \mu \mathrm{m}$ filter for immediate analysis of $\mathrm{Cr}(\mathrm{VI})$ and $\mathrm{pH}$ value.

\subsection{Analytical methods}

The $\mathrm{Cr}(\mathrm{VI})$ concentration was determined via the 1,5-diphenylcarbazide colorimetric method using a UVvisible spectrophotometer (UV2300, Shanghai, China) at a wavelength of $540 \mathrm{~nm}$. The total iron concentration was determined by the atomic absorption spectrometry (AA-6880F, Shimadzu, Japan). The $\mathrm{pH}$ and ORP values were measured using a pH meter (PHS-3C, Sanxin, China). The SS and VSS were determined following the standard methods for examining water and wastewater (Rice 2012). Ammonia, nitrite, nitrate and sulfate were determined by an ion chromatograph (Thermo Fisher, Dionex ICS-1100, USA).

At the end of the sulfate effect experiment, the abiotic and biotic $\mathrm{Fe}^{0}$ columns were disassembled and the packing materials at a location of $15-25 \mathrm{~cm}$ (effluent section) from the inlet were collected immediately in the anaerobic chamber and freeze-dried, then stored in the anaerobic chamber for iron-sample pretreatment before solid phase analysis (less than $2 \mathrm{~d}$ preservation). Magnetic separation was used to screen out the reacted iron. The collected iron samples were then observed using a scanning electron microscope (SEM) (ZEISS Merlin, Germany) equipped with an energy-dispersive X-ray (EDX) spectrometer. The fine surface coatings of the reacted iron were collected by grinding and polishing the iron samples in the anaerobic chamber, and subsequently sieved through a 100-mesh sifter, prior to the analysis of X-ray diffraction (XRD). The XRD of the fine surface coatings was conducted using a D8 ADVANCE (Bruker, Germany) diffractometer with $\mathrm{Cu}-\mathrm{Ka}$ radiation at $40 \mathrm{kV}$ to identify mineral phases on the reacted iron surface.

\subsection{Data analysis}

To provide an applicable model for engineering design, the removal capacity of $\mathrm{Fe}^{0}$ for $\mathrm{Cr}(\mathrm{VI})$ was estimated using the migration rate of $\mathrm{Cr}(\mathrm{VI})$ front as it moved gradually to the top of the column in the continuous-flow system. According to Lai's study (Lai \& Lo 2008), the $\mathrm{Cr}(\mathrm{VI})$ removal capacity ( $R C$, mg $\left.\mathrm{Cr}(\mathrm{VI}) \mathrm{g}^{-1} \mathrm{Fe}^{0}\right)$, can be estimated as follow (Eq. 1): 
$R C=\frac{[\mathrm{Cr}(\mathrm{VI})]}{M \times 1000 \times \rho_{\mathrm{b}}}$

where $[\mathrm{Cr}(\mathrm{VI})]$ is the influent $\mathrm{Cr}(\mathrm{VI})$ concentration. $M\left(\mathrm{~cm} \mathrm{~cm}^{-3}\right)$ is the normalized migration rate of $\mathrm{Cr}(\mathrm{VI})$ front at a relative concentration $\left(C / C_{0}\right)$ of 0.5 , which is the migration rate $\left(\mathrm{cm} \mathrm{PV}^{-1}\right)$ divided by the pore volume $\left(\mathrm{cm}^{3} \mathrm{PV}^{-1}\right)$. In this study, the migration rates of $\operatorname{Cr}(\mathrm{VI})$ fronts at $C / C_{0}$ of 0.5 can be calculated from the slopes of fitting lines of the PV-column length plots. And $\rho_{\mathrm{b}}\left(\mathrm{g} \mathrm{cm}^{-3}\right)$ is the bulk density of Fe packed in the columns.

\section{Results And Discussion}

\section{1 $\mathrm{Cr}(\mathrm{VI})$ removal in different systems}

In the control sand and cell columns, the effluent concentrations of $\mathrm{Cr}(\mathrm{VI})$ increased sharply and the $\mathrm{Cr}(\mathrm{VI})$ breakthrough occurred early in the first few PV. These indicated that $\mathrm{Cr}(\mathrm{VI})$ was neither reactive nor adsorptive in the sand and cell columns.

The $\mathrm{Cr}(\mathrm{VI})$-breakthrough curves illustrated in Fig. 1a and b show the $\mathrm{Cr}(\mathrm{VI})$ migration patterns in the abiotic and biotic $\mathrm{Fe}^{0}$ columns. Due to the passivation of $\mathrm{Fe}-\mathrm{Cr}$ precipitates, a relatively rapid breakthrough of $126 \mathrm{PV}$ occurred in the abiotic $\mathrm{Fe}^{0}$ column and the $\mathrm{Cr}(\mathrm{VI})$ removal capacity listed in Table 1 was $3.4 \mathrm{mg} \mathrm{Cr} \mathrm{g}^{-1} \mathrm{Fe}^{0}$. In contrast, with the inoculation of microorganisms, hydrogen-using bacteria could improve $\mathrm{Cr}(\mathrm{VI})$ removal by catching cathodic hydrogen as electron donors and effectively accelerating iron utilization inside the column (Yin et al. 2017). Therefore, the $\mathrm{Cr}(\mathrm{VI})$ removal performance in the biotic $\mathrm{Fe}^{0}$ column was greatly improved that its penetration time reached $218 \mathrm{PV}$ and the $\mathrm{Cr}(\mathrm{VI})$ removal capacity was recorded as $5.9 \mathrm{mg} \mathrm{Cr} \mathrm{g}^{-1} \mathrm{Fe}^{0}$, which were $73 \%$ and $74 \%$ higher than the abiotic one, respectively. In the following study, the data above also served as a baseline to evaluate the effects of different electron donors and electron acceptors on the removal of $\operatorname{Cr}(\mathrm{VI})$. 
Table 1

$\mathrm{Cr}(\mathrm{VI})$ removal capacities in the abiotic and biotic columns with different supplements

\begin{tabular}{|c|c|c|c|}
\hline Column & Reactive media & Supplement (mg L $\left.\mathrm{L}^{-1}\right)$ & $R C^{a}\left(\mathrm{mg} \mathrm{g}^{-1}\right)$ \\
\hline & & Blank & \\
\hline 1 & Abiotic $\mathrm{Fe}^{0}$ & - & 3.4 \\
\hline \multirow[t]{2}{*}{2} & Biotic $\mathrm{Fe}^{0}$ & - & 5.9 \\
\hline & & Sodium acetate (as COD) & \\
\hline 3 & Abiotic $\mathrm{Fe}^{0}$ & 10 & 3.5 \\
\hline 4 & Biotic $\mathrm{Fe}^{0}$ & 10 & 5.8 \\
\hline 5 & Abiotic $\mathrm{Fe}^{0}$ & 100 & 4.3 \\
\hline \multirow[t]{2}{*}{6} & Biotic $\mathrm{Fe}^{0}$ & 100 & 8.4 \\
\hline & & Humic acid (as COD) & \\
\hline 7 & Abiotic $\mathrm{Fe}^{0}$ & 5 & 3.5 \\
\hline 8 & Biotic $\mathrm{Fe}^{0}$ & 5 & 5.9 \\
\hline 9 & Abiotic $\mathrm{Fe}^{0}$ & 50 & 3.0 \\
\hline \multirow[t]{2}{*}{10} & Biotic Fe ${ }^{0}$ & 50 & 6.6 \\
\hline & & NO- 3-N & \\
\hline 11 & Abiotic $\mathrm{Fe}^{0}$ & 5 & 3.2 \\
\hline 12 & Biotic $\mathrm{Fe}^{0}$ & 5 & 5.0 \\
\hline 13 & Abiotic $\mathrm{Fe}^{0}$ & 50 & 3.0 \\
\hline \multirow[t]{2}{*}{14} & Biotic $\mathrm{Fe}^{0}$ & 50 & 3.9 \\
\hline & & $\mathrm{SO}_{4}{ }^{2-}$ & \\
\hline 15 & Abiotic $\mathrm{Fe}^{0}$ & 100 & 3.2 \\
\hline 16 & Biotic $\mathrm{Fe}^{0}$ & 100 & 10.3 \\
\hline 17 & Abiotic $\mathrm{Fe}^{0}$ & 800 & 5.4 \\
\hline 18 & Biotic Fe $\mathrm{F}^{0}$ & 800 & 12.4 \\
\hline
\end{tabular}




\section{Column Reactive media Supplement $\left(\mathrm{mg} \mathrm{L}^{-1}\right) \quad R C^{a}\left(\mathrm{mg} \mathrm{g}^{-1}\right)$ \\ ${ }^{a} R C$ is short for removal capacity of $\mathrm{Cr}(\mathrm{VI})$ \\ 3.2 Effect of sodium acetate (SA)}

The effect of sodium acetate at $10 \mathrm{mg} \mathrm{L}^{-1}$ and $100 \mathrm{mg} \mathrm{L}^{-1}$ as COD is shown in Fig. 2. When a low concentration of SA (10 $\mathrm{mg} \mathrm{L}^{-1}$ as COD) was applied, there was no obvious influence on $\mathrm{Cr}(\mathrm{VI})$ removal in both columns in comparison with the control columns. However, when a moderately higher concentration of SA (100 $\mathrm{mg} \mathrm{L}^{-1}$ as COD) was added, both abiotic and biotic Fe ${ }^{0}$ columns demonstrated elevated $\mathrm{Cr}(\mathrm{VI})$ removal performance. In the abiotic $\mathrm{Fe}^{0}$ column, the $\mathrm{Cr}(\mathrm{VI})$ breakthrough occurred at $153 \mathrm{PV}$ and the corresponding removal capacity was $4.3 \mathrm{mg} \mathrm{Cr} \mathrm{g}^{-1} \mathrm{Fe}^{0}$. As for the biotic $\mathrm{Fe}^{0}$ column, it showed much remarkable improvement that the $\mathrm{Cr}(\mathrm{VI})$ removal process lasted till $364 \mathrm{PV}$ and the corresponding removal capacity was calculated to be $8.4 \mathrm{mg} \mathrm{Cr} \mathrm{g}^{-1} \mathrm{Fe}^{0}$. Under the condition of an adequate SA, the lifespan and $\mathrm{Cr}(\mathrm{VI})$ removal capacity in the biotic $\mathrm{Fe}^{0}$ column were improved by $138 \%$ and $95 \%$, respectively, compared to the abiotic $\mathrm{Fe}^{0}$ column. Due to the low dosage of iron, hydrogen production was limited, and the water condition was an oligotrophic type. Therefore, the addition of SA was able to meet the desire for energy and reactivate the microorganisms inside the column since SA was an excellent substrate that could be efficiently utilized by the bacteria (He et al. 2002). In the abiotic Fe ${ }^{0}$ system, SA did not react with the $\mathrm{Fe}^{0}$ and had no effect on the buffer capacity of solution. For these reasons, the abiotic $\mathrm{Fe}^{0} \mathrm{column}$ did not show a conspicuous improvement on $\mathrm{Cr}(\mathrm{VI})$ removal and its slight enhancement could be explained by the microbial breeding in the column.

\subsection{Effect of humic acid (HA)}

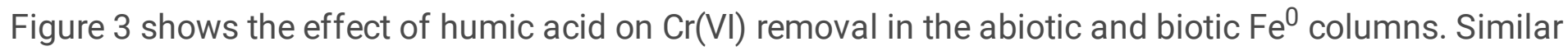
to the effect of sodium acetate, no significant changes were found when a low concentration of HA was applied (5 mg L $\mathrm{mg}^{-1}$ as COD). When the influent HA concentration reached $50 \mathrm{mg} \mathrm{L}^{-1}$ as COD, a slight inhibition was observed in the abiotic $\mathrm{Fe}^{0}$ column. The longevity of the abiotic column decreased from $128 \mathrm{PV}$ to $114 \mathrm{PV}$, and the corresponding $\mathrm{Cr}(\mathrm{VI})$ removal capacity decreased from 3.5 to $3.0 \mathrm{mg} \mathrm{Cr} \mathrm{g}^{-1}$ $\mathrm{Fe}^{0}$, compared to the low concentration of humic acid. The decrease in $\mathrm{Cr}(\mathrm{VI})$ removal performance of the abiotic $\mathrm{Fe}^{0}$ column was attributed to the deposition of $\mathrm{HA}$ on the $\mathrm{Fe}^{0}$ surface. As the influent contained cations such as $\mathrm{Fe}^{2+} / \mathrm{Fe}^{3+}$ and $\mathrm{Ca}^{2+}, \mathrm{HA}$ could form aggregates and then deposit on iron surfaces, which inhibited electron transfer originated from Fe ${ }^{0}$ (Liu et al. 2009a, Mak et al. 2011a, Mak et al. 2011b). Thereby, the $\mathrm{Cr}(\mathrm{VI})$ removal in the abiotic $\mathrm{Fe}^{0}$ column was affected. Nevertheless, in the biotic $\mathrm{Fe}^{0}$ system, $50 \mathrm{mg} \mathrm{L}^{-1} \mathrm{HA}$ slightly promoted the removal of $\mathrm{Cr}(\mathrm{VI})$. The life-span of the biotic $\mathrm{Fe}^{0}$ column was extended from $224 \mathrm{PV}$ to $252 \mathrm{PV}$, and the corresponding $\mathrm{Cr}(\mathrm{VI})$ removal capacity increased from 5.9 to 6.6 mg $\mathrm{Cr} \mathrm{g}^{-1} \mathrm{Fe}^{0}$ in comparison with the condition of low HA dosage. The observation revealed that in a $\mathrm{HA}$ concentration of $50 \mathrm{mg} \mathrm{L}^{-1}$ as COD, the microorganisms could use HA as a carbon source to provide needed energy for their metabolism and enhance their activity for the synergistic interaction with $\mathrm{Fe}^{0}$. 
Besides, by utilizing HA, the deposition of HA on the iron surface might be effectively cleaned up, thus maintaining the reactivity of iron surface.

\subsection{Effect of nitrate $\left(\mathrm{NO}_{3}{ }^{-}\right)$}

To investigate the effect of nitrate on $\mathrm{Cr}(\mathrm{VI})$ removal, 5 and $50 \mathrm{mg} \mathrm{L}^{-1} \mathrm{NO}_{3}{ }^{-}-\mathrm{N}$ were added respectively to the simulated $\mathrm{Cr}(\mathrm{VI})$-contaminated groundwater and the corresponding $\mathrm{Cr}(\mathrm{VI})$ breakthrough curves in different systems are shown in Fig. 4. As Fig. 4 and Table 1 demonstrated, the presence of $\mathrm{NO}_{3}{ }^{-}$had a minor inhibitory effect on removing $\mathrm{Cr}(\mathrm{VI})$ in the abiotic $\mathrm{Fe}^{0}$ column whereas it significantly inhibited the $\mathrm{Cr}(\mathrm{VI})$ removal performance of the biotic $\mathrm{Fe}^{0}$ column. And these inhibition effects were positively related to the initial concentration of $\mathrm{NO}_{3}{ }^{-} \mathrm{N}$. When the nitrate concentration increased from 5 to $50 \mathrm{mg} \mathrm{L}^{-1}$ as $\mathrm{NO}_{3}{ }^{-}-\mathrm{N}$, the $\mathrm{Cr}(\mathrm{VI})$ penetration time in the abiotic $\mathrm{Fe}^{0}$ column decreased from 108 to $98 \mathrm{PV}$, and the corresponding $\mathrm{Cr}(\mathrm{VI})$ removal capacity decreased from 3.2 to $3.0 \mathrm{mg} \mathrm{Cr} \mathrm{g}^{-1} \mathrm{Fe}^{0}$. As for the biotic $\mathrm{Fe}^{0}$ system, the $\mathrm{Cr}(\mathrm{VI})$ removal process shortened from 184 to $132 \mathrm{PV}$, and the corresponding $\mathrm{Cr}(\mathrm{VI})$ removal capacity decreased from 5.0 to $3.9 \mathrm{mg} \mathrm{Cr} \mathrm{g}^{-1} \mathrm{Fe}^{0}$. Compared to the control abiotic $\mathrm{Fe}^{0}$ system, there were approximately $14-22 \%$ decline of operation time and $6-13 \%$ decrease of $\operatorname{Cr}(\mathrm{VI})$ removal capacity respectively, when 5 and $50 \mathrm{mg} \mathrm{L}^{-1} \mathrm{NO}_{3}{ }^{-}-\mathrm{N}$ were added in the abiotic column. Correspondingly, when 5 and $50 \mathrm{mg} \mathrm{L}^{-1} \mathrm{NO}_{3}{ }^{-} \mathrm{N}$ were fed, the biotic $\mathrm{Fe}^{0}$ column showed a $16-39 \%$ decrease in longevity and an 18-51\% decline in $\mathrm{Cr}(\mathrm{VI})$ removal capacity respectively, in comparison with the control biotic $\mathrm{Fe}^{0}$ column.

It is reported that $\mathrm{Fe}^{0}$ can reduce nitrate to produce ammonia $\left(\mathrm{NH}_{4}{ }^{+}\right)$and nitrite or even be adsorbed by its corrosion products (Liu \&Wang 2019). For further verification, the effluent concentration of nitrate and ammonia in both abiotic and biotic $\mathrm{Fe}^{0}$ columns with $50 \mathrm{mg} \mathrm{L}^{-1} \mathrm{NO}_{3}{ }^{-} \mathrm{N}$ were also examined and their trends are shown in Fig. 4e and $\mathrm{f}$. In the beginning, a decrease of $\mathrm{NO}_{3}{ }^{-} \mathrm{N}$ and a rapid increase of $\mathrm{NH}_{4}{ }^{+}-\mathrm{N}$ were detected in both columns. At the first $12 \mathrm{PV}$, the effluent concentration of $\mathrm{NO}_{3}{ }^{-} \mathrm{N}$ in the abiotic $\mathrm{Fe}^{0}$ column decreased from 48.2 to $42.9 \mathrm{mg} \mathrm{L}^{-1}$, and the $\mathrm{NH}_{4}{ }^{+}-\mathrm{N}$ increased simultaneously from 0 to $4.8 \mathrm{mg}$ $\mathrm{L}^{-1}$. For the biotic $\mathrm{Fe}^{0}$ system, a much significant decrease of $\mathrm{NO}_{3}{ }^{-} \mathrm{N}$ from 48.2 to $35.7 \mathrm{mg} \mathrm{L}^{-1}$ was observed, and the $\mathrm{NH}_{4}{ }^{+}-\mathrm{N}$ increased sharply from 0 to $10.9 \mathrm{mg} \mathrm{L}^{-1}$. These results suggested that nitrate reduction occurred in abiotic and biotic $\mathrm{Fe}^{0}$ columns. Additionally, it was also important to find that, in the biotic $\mathrm{Fe}^{0}$ column, a much higher reduction of nitrate was observed and the nitrate removal process was much longer than the abiotic system. Moreover, the mass of nitrogen examined in the biotic column was not conserved. This observation might also imply that the nitrate could be partially removed through the denitrification process of microorganisms. Meanwhile, under the clearance and acceleration of microbe, higher utilization of iron and more extensive production of reactive minerals could be achieved, thus resulting in a higher nitrate reduction efficiency as well as higher ammonia generation. This observation was consistent with Gandhi's study that the mixed sludge with denitrifying bacteria could effectively improve the denitrification efficiency of conventional $\mathrm{Fe}^{0}$ systems (Gandhi et al. 2002). 
Overall, the observed results indicated that nitrate could serve as an electron acceptor and react easily with $\mathrm{Fe}^{0}$ and microorganisms. That is, this denitrification process might compete with $\mathrm{Cr}(\mathrm{VI})$ for electrons and adsorption sites so that the removal process of $\mathrm{Cr}(\mathrm{VI})$ was inhibited. Nevertheless, nitrate has been reported to be a positive anion for the $\mathrm{Fe}^{0}-\mathrm{H}_{2} \mathrm{O}$ system to remove reducible contaminants since nitrate can promote the generation of magnetite, which can facilitate electron transfer in the $\mathrm{Fe}^{0}-\mathrm{H}_{2} \mathrm{O}$ system (Wei et al. 2016). Those reports seem conflictive with the present study. In this experiment, as the iron dosage was low, the columns were easily passivated by $\mathrm{Cr}(\mathrm{VI})$ or nitrate in a relatively short time, which was unfavorable for $\mathrm{NO}_{3}{ }^{-}$and $\mathrm{Fe}^{0}$ to interact fully and generate magnetite, thus resulting in an entirely inhibitory phase. But it is also important to point out that the biotic $\mathrm{Fe}^{0}$ system is vulnerable to treat $\mathrm{Cr}(\mathrm{VI})$-contaminated groundwater when nitrate is present.

\subsection{Effect of sulfate $\left(\mathrm{SO}_{4}{ }^{2-}\right)$}

Similar to nitrate, sulfate is a common contaminant and an electron acceptor frequently found in groundwater. The effect of $\mathrm{SO}_{4}{ }^{2-}$ on $\mathrm{Cr}(\mathrm{VI})$ removal in the biotic $\mathrm{Fe}^{0}$ column is shown in Fig. 5. The presence of $\mathrm{SO}_{4}{ }^{2-}$ promoted the $\mathrm{Cr}(\mathrm{VI})$ removal performance in both abiotic and biotic $\mathrm{Fe}^{0}$ columns. When initial $\mathrm{SO}_{4}{ }^{2-}$ concentration was set at a relatively low value of $100 \mathrm{mg} \mathrm{L}^{-1}$, there was no difference between the abiotic $\mathrm{Fe}^{0}$ and control columns. Whereas, as the $\mathrm{SO}_{4}{ }^{2-}$ concentration increased to $800 \mathrm{mg}$ $\mathrm{L}^{-1}$, the operational life of the abiotic $\mathrm{Fe}^{0}$ column increased to $228 \mathrm{PV}$ and the $\mathrm{Cr}(\mathrm{VI})$ removal capacity was $5.4 \mathrm{mg} \mathrm{Cr} / \mathrm{g} \mathrm{Fe}^{0}$, which were $81 \%$ and $59 \%$ higher than the abiotic control $\mathrm{Fe}^{0}$ column. In the biotic $\mathrm{Fe}^{0}$ column, the $\mathrm{Cr}(\mathrm{VI})$ breakthrough occurred at 392 and $512 \mathrm{PV}$ respectively, when 100 and $800 \mathrm{mg} \mathrm{L}^{-1}$ $\mathrm{SO}_{4}{ }^{2-}$ was applied, and the corresponding $\mathrm{Cr}(\mathrm{VI})$ removal capacities were 10.3 and $12.4 \mathrm{mg} \mathrm{Cr} \mathrm{g}^{-1} \mathrm{Fe}^{0}$, respectively. In comparison with the biotic control $\mathrm{Fe}^{0}$ column, the longevity of the biotic $\mathrm{Fe}^{0}$ column at 100 and $800 \mathrm{mg} \mathrm{L}^{-1}$ of $\mathrm{SO}_{4}{ }^{2-}$ were promoted by $80 \%$ and $134 \%$, respectively, and the corresponding $\mathrm{Cr}(\mathrm{VI})$ removal capacity increased by $75 \%$ and $110 \%$.

The presence of sulfate led to a more vigorous promotion on $\mathrm{Cr}(\mathrm{VI})$ removal in the biotic $\mathrm{Fe}^{0}$ system than the abiotic one. On the one hand, sulfate was reported to maintain the iron reactivity by removing the passive oxide film (Su \&Puls 2001). On the other hand, similar to bicarbonate, sulfate also could migrate to the interlayer position of iron hydroxides to form green rust, which were generally considered to be a reactive mineral that could serve as chemical-conductor or reductant for $\mathrm{Cr}(\mathrm{VI})$ removal (Eq. 2) (Liu et al. 2015, Van et al. 2008).

$4 \mathrm{Fe}^{2+}+2 \mathrm{Fe}^{3+}+\mathrm{SO}_{4}{ }^{2-}+12 \mathrm{H}_{2} \mathrm{O} \leftrightarrow \mathrm{Fe}_{6}(\mathrm{OH})_{12} \mathrm{SO}_{4}+12 \mathrm{H}^{+}$

Furthermore, the existence of $\mathrm{SO}_{4}{ }^{2-}$ could also alter the biochemical environment of the columns from the perspective of microorganisms. By examining the effluent concentration of $\mathrm{SO}_{4}{ }^{2-}$, a significant difference between the abiotic and biotic columns was found in Fig. $5 \mathrm{e}$ and $\mathrm{f}$. In the abiotic Fe ${ }^{0}$ column, the $\mathrm{SO}_{4}{ }^{2-}$ concentration in effluent did not change significantly with time. However, the effluent $\mathrm{SO}_{4}{ }^{2-}$ in 
the biotic $\mathrm{Fe}^{0}$ column suffered a decline first, then increased and became stable over time. This observation indicated that utilization or adsorption of sulfate by the microorganisms might occur in the biotic column. According to Watson's study, sulfate is a typical electron acceptor in water and the sulfatereducing bacteria (SRB) are able to reduce $\mathrm{SO}_{4}{ }^{2-}$ to $\mathrm{S}^{2-}$, then interact with aqueous $\mathrm{Fe}(\mathrm{II})$ to form amorphous ferrous sulfide (FeS) or Mackinawite (Watson et al. 2000, Watson et al. 1999). Unlike Fe(III) bearing oxides, these complex minerals have a relatively large specific surface area, which can adsorb or even reduce $\mathrm{Cr}(\mathrm{VI})$ by its structural $\mathrm{Fe}(\mathrm{II})$, thus providing abundant reactive sites for $\mathrm{Cr}(\mathrm{VI})$ removal (Van et al. 2007, Van et al. 2008). By examining the coatings on the iron surface, cocci-shaped bacteria and hexagonal-shaped minerals were confirmed on the biotic $\mathrm{Fe}^{0}$ surface using SEM whereas the abiotic Fe surface was compactly precipitated by $\mathrm{Fe}-\mathrm{Cr}$ (oxy)hydroxide or calcite (Fig. 6). Meanwhile, the XRD pattern result also confirmed larger quantities of various reactive minerals (e.g., mackinawite, green rust, lepidocrocite and magnetite) on the biotic $\mathrm{Fe}^{0}$ surface than the abiotic one (Fig. 6). Those results suggested that the existence of sulfate could not only maintain the reactivity of iron by suppressing the formation of passivated precipitates, but also could be utilized by SRB to form highly reactive minerals, thereby resulting in a remarkable promotion on $\mathrm{Cr}(\mathrm{VI})$ removal in the biotic column. However, when the $\mathrm{SO}_{4}{ }^{2-}$ concentration increased from 100 to $800 \mathrm{mg} \mathrm{L}^{-1}$, there was no significant promotion on column longevity and $\mathrm{Cr}(\mathrm{VI})$ removal capacity in the biotic $\mathrm{Fe}^{0}$ column, which suggested that the limited microbes and hydraulic retention times in the column might limit further utilization of sulfate.

\section{Conclusions}

This study has investigated $\mathrm{Cr}(\mathrm{VI})$ removal performance in a biotic $\mathrm{Fe}^{0}$ system under different nutrient and electron-accepting conditions. According to the obtained results, sodium acetate was found to be an effective additional substrate for the biotic $\mathrm{Fe}^{0}$ system to remove $\mathrm{Cr}(\mathrm{VI})$. Humic acid could form passive precipitates on the iron surface and inhibit reaction from further progressing in the abiotic $\mathrm{Fe}^{0}$ system whereas the presence of humic acid enhanced $\mathrm{Cr}(\mathrm{VI})$ removal in the biotic system since microorganisms were able to utilize it and simultaneously clean up humic acid aggregates. But for the effects of electron acceptors, varied influences were observed in the biotic $\mathrm{Fe}^{0}$ system. Nitrate demonstrated an inhibitory effect on removing $\mathrm{Cr}(\mathrm{VI})$ as it might compete with $\mathrm{Cr}(\mathrm{VI})$ for electrons. On the contrary, sulfate could be reduced by SRB and generate highly reactive minerals such as green rust and iron sulfide, which could significantly enhance the column reactivity and $\mathrm{Cr}(\mathrm{VI})$ removal.

Based on the above results, the biotic $\mathrm{Fe}^{0}$ system still performed more applaudable $\mathrm{Cr}(\mathrm{VI})$ removal than the abiotic system under different nutrient and electron-accepting conditions. Therefore, a mixed culture is suggested as a potential addition to conventional $\mathrm{Fe}^{0}-\mathrm{H}_{2} \mathrm{O}$ systems since organic substrates (e.g., sodium acetate and humic acid) are favored by biotic treatment and provide extra energy for removing $\mathrm{Cr}(\mathrm{VI})$. Besides, this biotic $\mathrm{Fe}^{0}$ system can solve combined contaminations such as $\mathrm{Cr}(\mathrm{VI})$-nitrate and $\mathrm{Cr}(\mathrm{VI})$-sulfate contaminated groundwater. However, in order to achieve a better removal performance for 
desired contaminants, the co-existence of organic substrates and electron acceptors should also be taken into account when applying biotic $\mathrm{Fe}^{0}$ systems.

\section{Declarations}

\section{Acknowledgement}

The authors thank the support from the National Key R\&D Program of China (2019YFC1805900), the National Natural Science Foundation of China $(41977114,41807338)$.

\section{Authors' contributions}

Weiquan Li: Writing - Original Draft, Conceptualization, Methodology and Data curation.

Mingxi Li: Formal analysis and Software.

Weizhao Yin: Supervision, Writing.

Sihao Lv: Writing- Reviewing and Editing.

Jiawei Zhong: Formal analysis and Software.

Ping Li: Project administration.

Hong Deng: Supervision.

Jinhua Wu: Project administration and Funding acquisition.

\section{Competing Interests}

The authors declare that they have no known competing financial interests or personal relationships that could have appeared to influence the work reported in this paper.

\section{Ethical Approval and consent to participate}

This article does not contain any studies with human participants or animals performed by any of the authors.

\section{Consent to Publish}

Not applicable.

\section{References}


1. Battaglia-Brunet F, Foucher S, Denamur A, Ignatiadis I, Michel C, Morin D (2002) Reduction of chromate by fixed films of sulfate-reducing bacteria using hydrogen as an electron source. $\mathrm{J}$ Ind Microbiol Biot 28:154-159

2. Cao R, Liu S, Yang X, Wang C, Wang Y, Wang W, Pi Y (2022) Enhanced remediation of Cr(VI)contaminated groundwater by coupling electrokinetics with ZVI/Fe304/AC-based permeable reactive barrier. J Environ Sci 112:280-290

3. Chung J, Nerenberg R, Rittmann BE (2006) Bio-reduction of soluble chromate using a hydrogenbased membrane biofilm reactor. Water Res 40:1634-1642

4. Dinh HT, Kuever J, Mußmann M, Hassel AW, Stratmann M, Widdel F (2004) Iron corrosion by novel anaerobic microorganisms. Nature 427:829-832

5. Dries J, Bastiaens L, Springael D, Kuypers S, Agathos SN, Diels L (2005) Effect of humic acids on heavy metal removal by zero-valent iron in batch and continuous flow column systems. Water Res 39:3531-3540

6. Fitts CR (2002) Groundwater science. Elsevier

7. Gandhi S, Oh BT, Schnoor JL, Alvarez PJ (2002) Degradation of TCE, Cr(VI), sulfate, and nitrate mixtures by granular iron in flow-through columns under different microbial conditions. Water Res 36:1973-1982

8. Gheju M (2011) Hexavalent Chromium Reduction with Zero-Valent Iron (ZVI) in Aquatic Systems. Water Air Soil Pollut 222:103-148

9. GracePavithra K, Jaikumar V, Kumar PS, SundarRajan P (2019) A review on cleaner strategies for chromium industrial wastewater: Present research and future perspective. J Clean Prod 228:580593

10. Gu B, Phelps TJ, Liang L, Dickey MJ, Roh Y, Kinsall BL, Palumbo AV, Jacobs GK (1999) Biogeochemical Dynamics in Zero-Valent Iron Columns: Implications for Permeable Reactive Barriers. Environ Sci Technol 33:2170-2177

11. He J, Sung Y, Dollhopf ME, Fathepure BZ, Tiedje JM, Löffler FE (2002) Acetate versus hydrogen as direct electron donors to stimulate the microbial reductive dechlorination process at chloroethenecontaminated sites. Environ Sci Technol 36:3945-3952

12. Lai KCK, Lo IMC (2008) Removal of Chromium (VI) by Acid-Washed Zero-Valent Iron under Various Groundwater Geochemistry Conditions. Environ Sci Technol 42:1238-1244

13. Liu T, Rao P, Lo IM (2009a) Influences of humic acid, bicarbonate and calcium on $\mathrm{Cr}(\mathrm{VI})$ reductive removal by zero-valent iron. Sci Total Environ 407:3407-3414

14. Liu TZ, Rao PH, Mak MSH, Wang P, Lo IMC (2009b) Removal of co-present chromate and arsenate by zero-valent iron in groundwater with humic acid and bicarbonate. Water Res 43:2540-2548

15. Liu Y, Mou H, Chen L, Mirza ZA, Liu L (2015) Cr(VI)-contaminated groundwater remediation with simulated permeable reactive barrier (PRB) filled with natural pyrite as reactive material: Environmental factors and effectiveness. J Hazard Mater 298:83 
16. Liu Y, Wang J (2019) Reduction of nitrate by zero valent iron (ZVI)-based materials: A review. Sci Total Environ 671:388-403

17. Mak MS, Rao P, Lo IM (2011a) Zero-valent iron and iron oxide-coated sand as a combination for removal of co-present chromate and arsenate from groundwater with humic acid. Environ Pollut 159:377-382

18. Mak MSH, Lo IMC, Liu T (2011b) Synergistic effect of coupling zero-valent iron with iron oxidecoated sand in columns for chromate and arsenate removal from groundwater: Influences of humic acid and the reactive media configuration. Water Res 45:6575-6584

19. Niedzwiecka JB, Finneran KT (2015) Combined biological and abiotic reactions with iron and Fe(III)reducing microorganisms for remediation of explosives and insensitive munitions (IM). Environ SciWat Res 1:34-39

20. Oh B-T, Just CL, Alvarez PJJ (2001) Hexahydro-1,3,5-trinitro-1,3,5-triazine Mineralization by Zerovalent Iron and Mixed Anaerobic Cultures. Environ Sci Technol 35:4341-4346

21. Rice EW (2012) Standard Methods for Examination of Water and Wastewater 2012. Amer Public Health Assn

22. Richard FC, Bourg ACM (1991) Aqueous geochemistry of chromium: A review. Water Res 25:807816

23. Shin KH, Cha DK (2008) Microbial reduction of nitrate in the presence of nanoscale zero-valent iron. Chemosphere 72:257-262

24. Su C, Puls RW (2001) Arsenate and arsenite removal by zerovalent iron: effects of phosphate, silicate, carbonate, borate, sulfate, chromate, molybdate, and nitrate, relative to chloride. Environ Sci Technol 35:4562-4568

25. Van NT, Lieben F, Dries J, Pirard E, Springael D, Bastiaens L (2007) Impact of microbial activities on the mineralogy and performance of column-scale permeable reactive iron barriers operated under two different redox conditions. Environ Sci Technol 41:5724-5730

26. Van NT, Springael D, Bastiaens L (2008) Positive impact of microorganisms on the performance of laboratory-scale permeable reactive iron barriers. Environ Sci Technol 42:1680-1686

27. Wang Q, Song X, Wei C, Jin P, Chen X, Tang Z, Li K, Ding X, Fu H (2022) In situ remediation of Cr(VI) contaminated groundwater by ZVI-PRB and the corresponding indigenous microbial community responses: a field-scale study. Sci Total Environ 805:150260

28. Watson JHP, Ellwood DC, Soper AK, Charnock J (1999) Nanosized strongly-magnetic bacteriallyproduced iron sulfide materials. Journal of Magnetism \& Magnetic Materials 203:69-72

29. Watson JHP, Cressey BA, Roberts AP, Ellwood DC, Charnock JM, Soper AK (2000) Structural and magnetic studies on heavy-metal-adsorbing iron sulphide nanoparticles produced by sulphatereducing bacteria. Journal of Magnetism \& Magnetic Materials 214:13-30

30. Wei M, Fang $Y$, Huang G, Chen $H$, Fei L (2016) Long-term effect of nitrate on $\mathrm{Cr}(\mathrm{VI})$ removal by $\mathrm{Fe}^{0}$. column studies. Environ Sci Pollut Res 23:8589-8597 
31. Wilkin RT, Su C, Ford RG, Paul CJ (2005) Chromium-Removal Processes during Groundwater Remediation by a Zerovalent Iron Permeable Reactive Barrier. Environ Sci Technol 39:4599-4605

32. Wu J, Yin W, Gu J, Li P, Wang X, Yang B (2013) A biotic Fe0-H2O system for nitrobenzene removal from groundwater. Chem Eng J 226:14-21

33. Yang ZL, Wang XL, Li H, Yang J, Zhou LY, Liu YD (2017) Re-activation of aged-ZVI by iron-reducing bacterium Shewanella putrefaciens for enhanced reductive dechlorination of trichloroethylene. J Chem Technol Biot 92:2642-2649

34. Yin W, Wu J, Huang W, Wei C (2015) Enhanced nitrobenzene removal and column longevity by coupled abiotic and biotic processes in zero-valent iron column. Chem Eng J 259:417-423

35. Yin W, Wu J, Huang W, Li Y, Jiang G (2016) The effects of flow rate and concentration on nitrobenzene removal in abiotic and biotic zero-valent iron columns. Sci Total Environ 560-561:1218

36. Yin W, Li Y, Wu J, Chen G, Jiang G, Li P, Gu J, Liang H, Liu C (2017) Enhanced Cr(VI) removal from groundwater by $\mathrm{Fe}^{0}-\mathrm{H}_{2} \mathrm{O}$ system with bio-amended iron corrosion. $\mathrm{J}$ Hazard Mater 332:42-50

37. Zhitkovich A (2011) Chromium in Drinking Water: Sources, Metabolism, and Cancer Risks. Chem Res Toxicol 24:1617-1629

38. Zhong J, Yin W, Li Y, Li P, Wu J, Jiang G, Gu J, Liang H (2017) Column study of enhanced Cr(VI) removal and longevity by coupled abiotic and biotic processes using $\mathrm{Fe}(0)$ and mixed anaerobic culture. Water Res 122:536-544

\section{Figures}
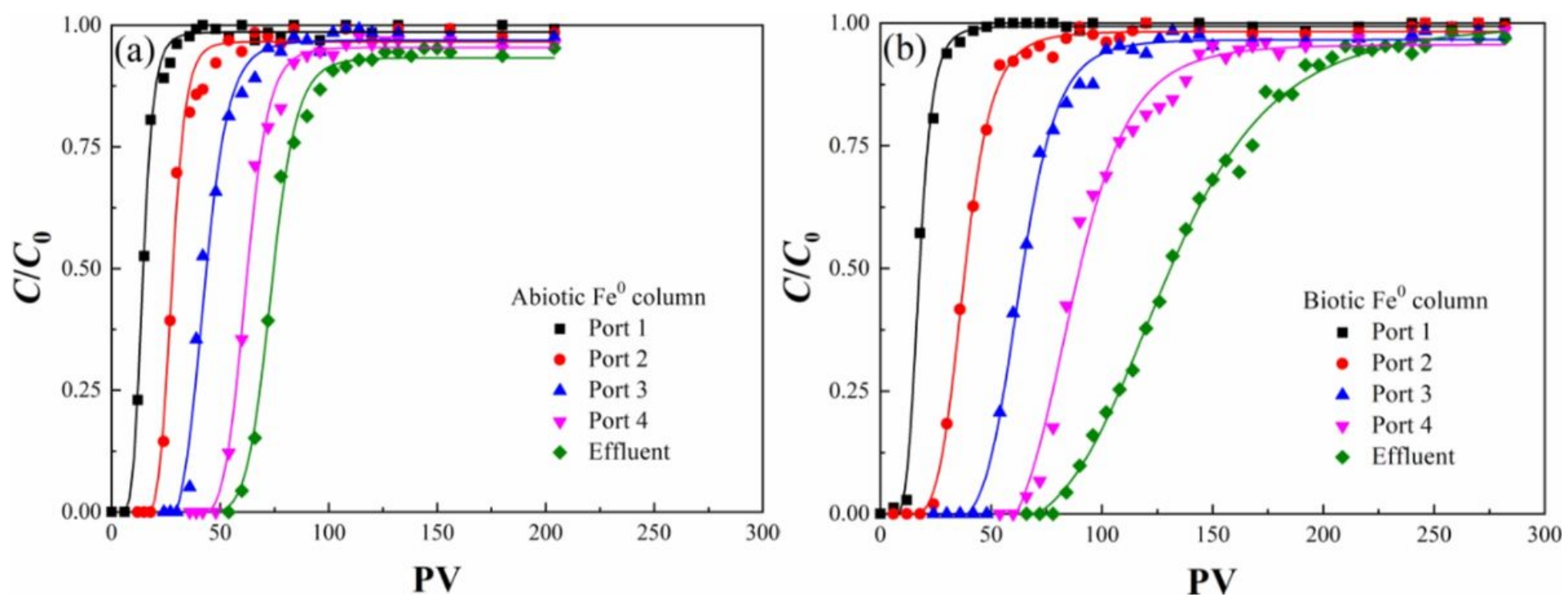

Figure 1

$\mathrm{Cr}(\mathrm{VI})$ breakthrough curves in the abiotic and biotic $\mathrm{Fe}^{0}$ columns (influent $\mathrm{Cr}(\mathrm{VI})$ was $10 \mathrm{mg} \mathrm{L}^{-1} ; 1 \mathrm{PV}$ stood for $2 \mathrm{~h}$ operation time; seepage velocity was $569 \mathrm{~m}^{\text {year }}{ }^{-1}$; influent $\mathrm{pH}$ was $7.0 \pm 0.1$; influent ORP 

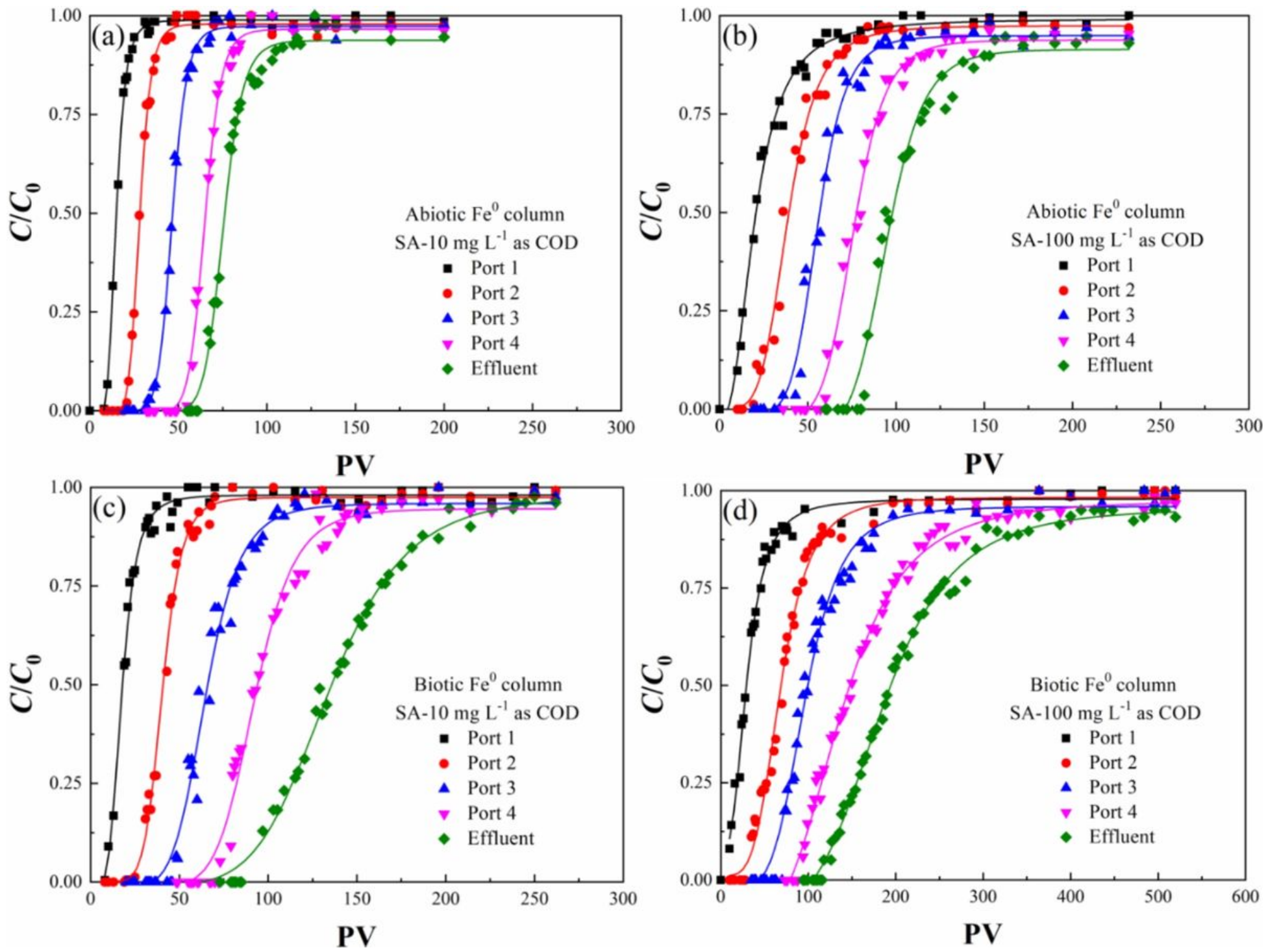

Figure 2

Effect of sodium acetate on $\mathrm{Cr}(\mathrm{VI})$ removal ((a) and (b) were the breakthrough curves of the abiotic $\mathrm{Fe}^{0}$ column conducted at 10 and $100 \mathrm{mg} / \mathrm{L} \mathrm{COD}$, respectively; (c) and (d) were the breakthrough curves of the biotic $\mathrm{Fe}^{0}$ column conducted at 10 and $100 \mathrm{mg} / \mathrm{L} \mathrm{COD}$, respectively) 

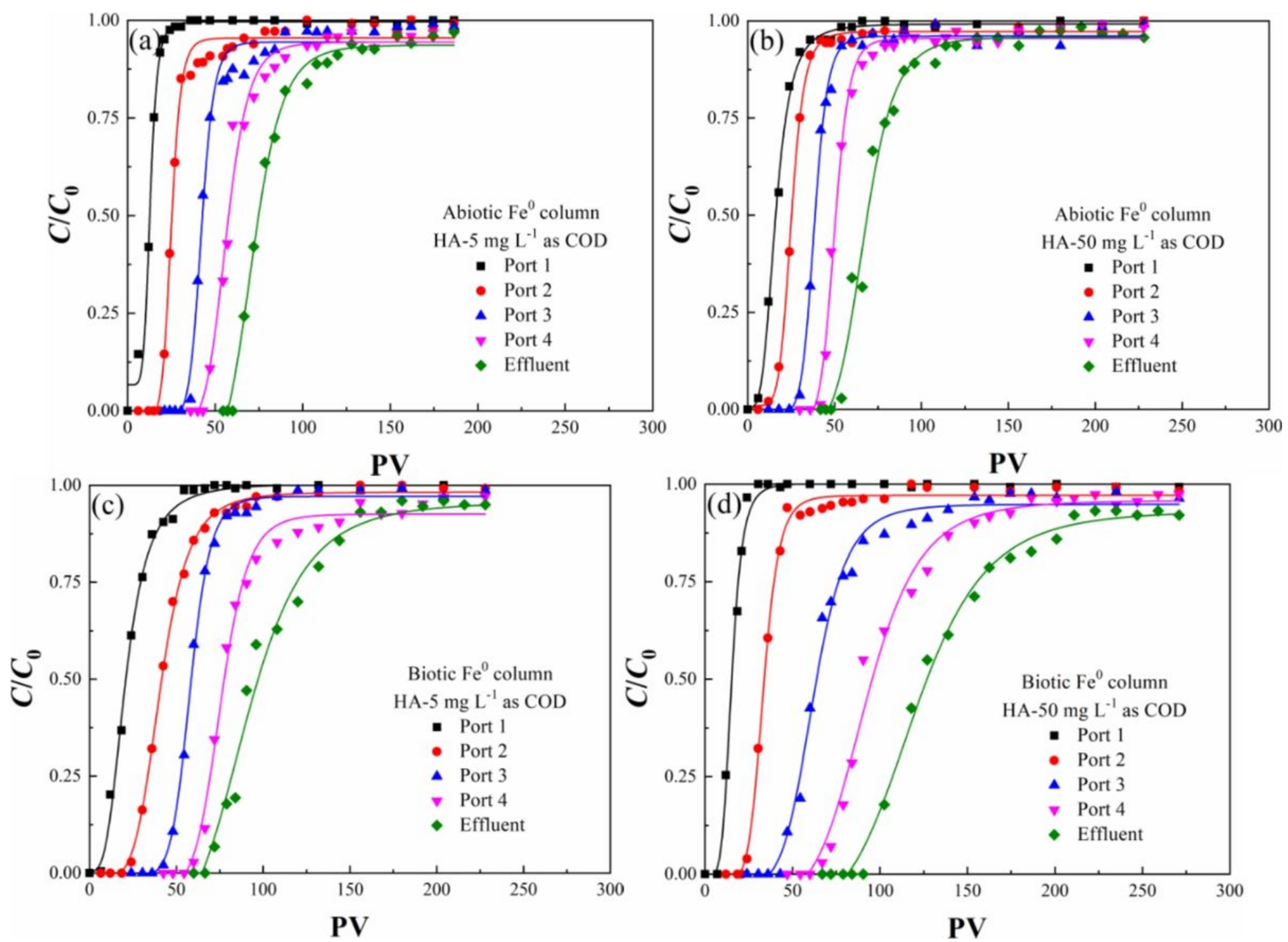

Figure 3

Effect of humic acid on $\mathrm{Cr}(\mathrm{VI})$ removal $\left((\mathrm{a})\right.$ and $(\mathrm{b})$ were the breakthrough curves of the abiotic $\mathrm{Fe}^{0}$ column conducted at 5 and $50 \mathrm{mg} \mathrm{L}^{-1}$ COD, respectively; (c) and (d) were the breakthrough curves of the biotic $\mathrm{Fe}^{0}$ column conducted at 5 and $50 \mathrm{mg} \mathrm{L}^{-1}$ as COD, respectively) 

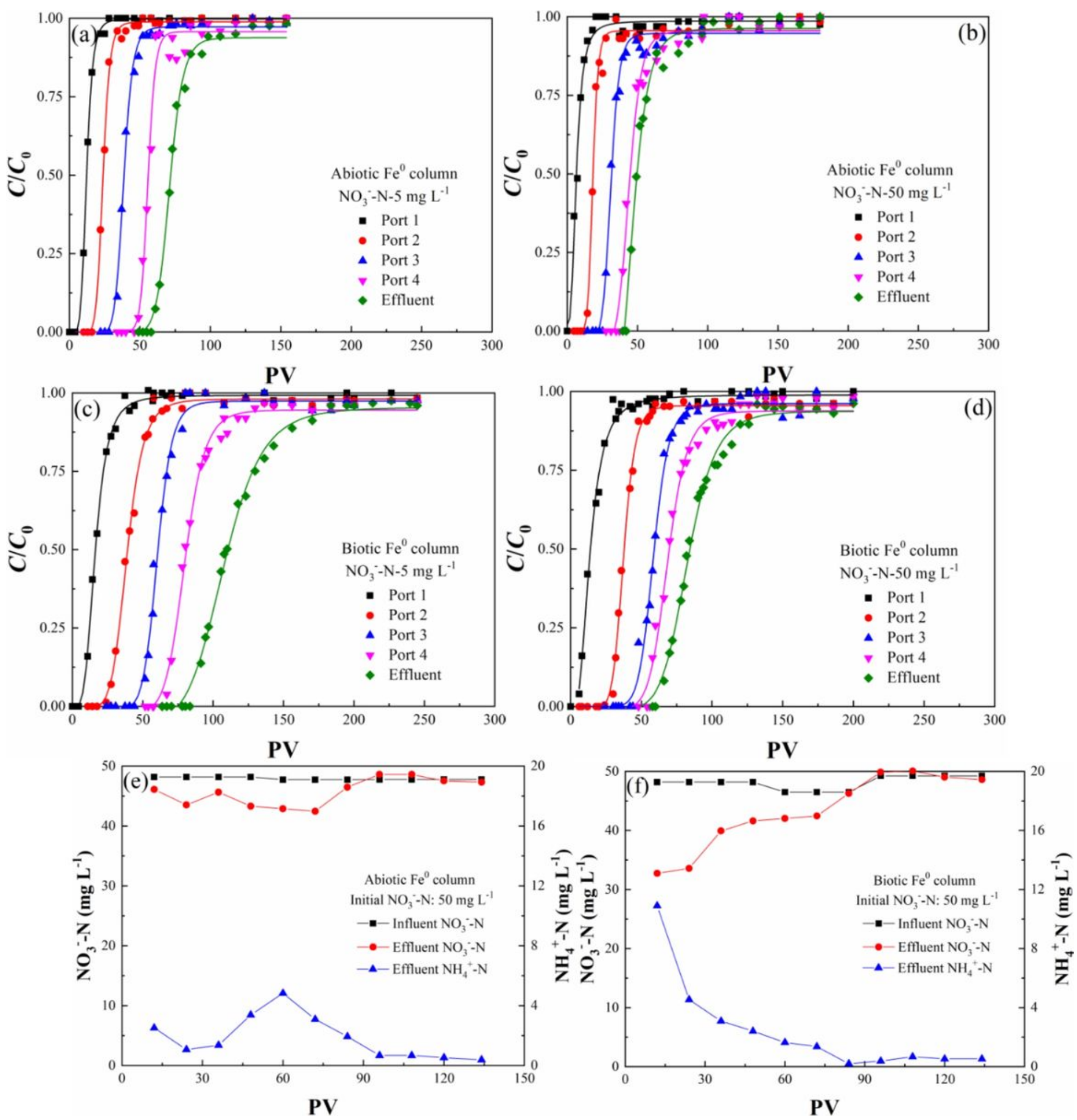

Figure 4

(a)-(d) Effect of nitrate on $\mathrm{Cr}(\mathrm{VI})$ removal ((a) and (b) were the breakthrough curves of the abiotic $\mathrm{Fe}^{0}$ column conducted at 5 and $50 \mathrm{mg} \mathrm{L}^{-1} \mathrm{NO}_{3}{ }^{-} \mathrm{N}$, respectively; (c) and (d) were the breakthrough curves of the biotic $\mathrm{Fe}^{0}$ column conducted at 5 and $50 \mathrm{mg} \mathrm{L}^{-1} \mathrm{NO}_{3}{ }^{-} \mathrm{N}$, respectively); (e)-(f) the concentration of nitrate and ammonia in the abiotic and biotic $\mathrm{Fe}^{0}$ columns 

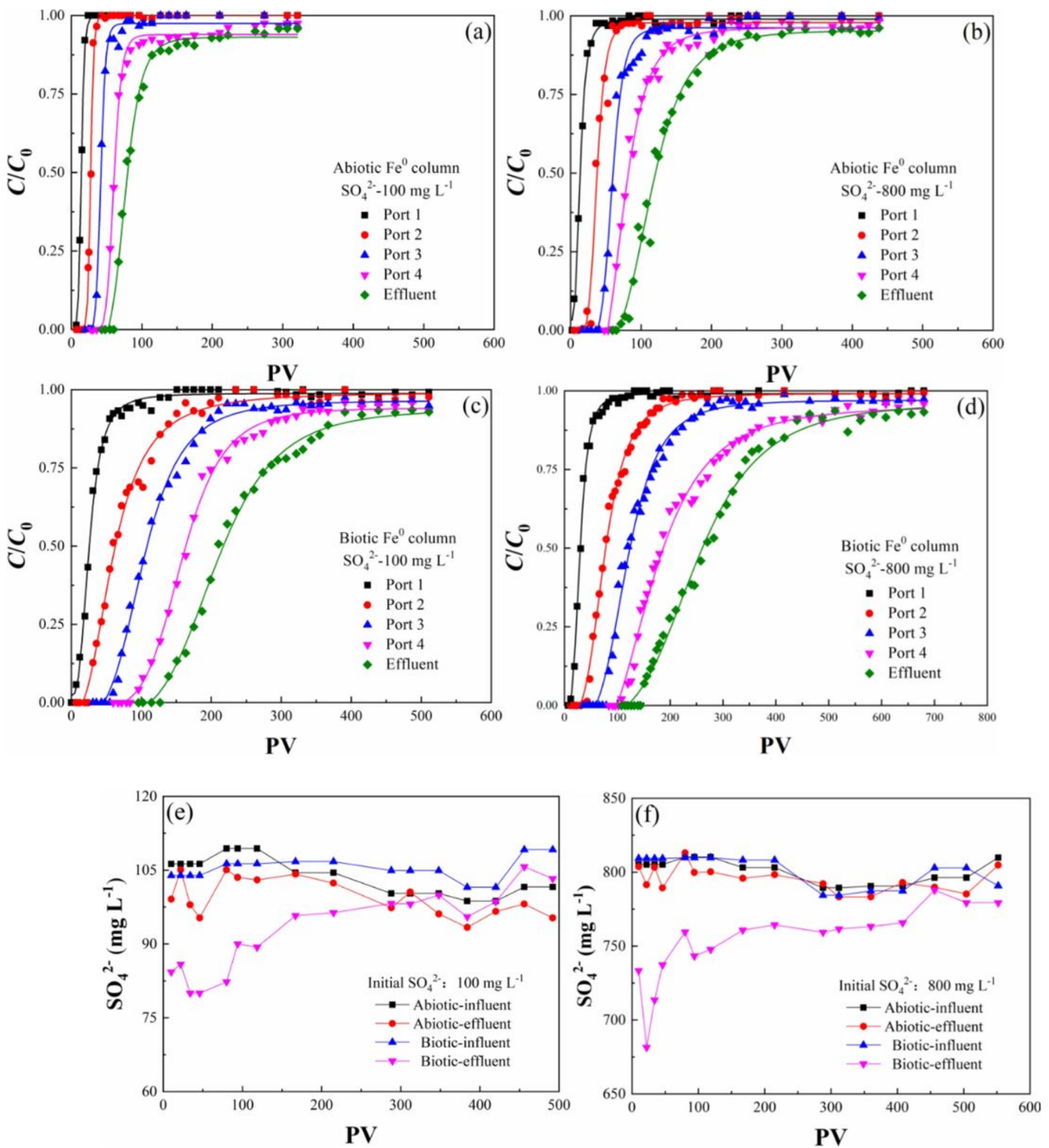

Figure 5

(a)-(d) Effect of sulfate on $\mathrm{Cr}(\mathrm{VI})$ removal ((a) and (b) were the breakthrough curves of the abiotic $\mathrm{Fe}^{0}$ column conducted at 100 and $800 \mathrm{mg} \mathrm{L}^{-1} \mathrm{SO}_{4}{ }^{2}$, respectively; (c) and (d) were the breakthrough curves of the biotic $\mathrm{Fe}^{0}$ column conducted at 100 and $800 \mathrm{mg} \mathrm{L}^{-1} \mathrm{SO}_{4}{ }^{2}$, respectively); (e)-(f) Effluent concentration 
of sulfate in the abiotic and biotic Fe columns ((e) and (f) were conducted at 100 and $800 \mathrm{mg} \mathrm{L}^{-1} \mathrm{SO}_{4}{ }^{2-}$, respectively)
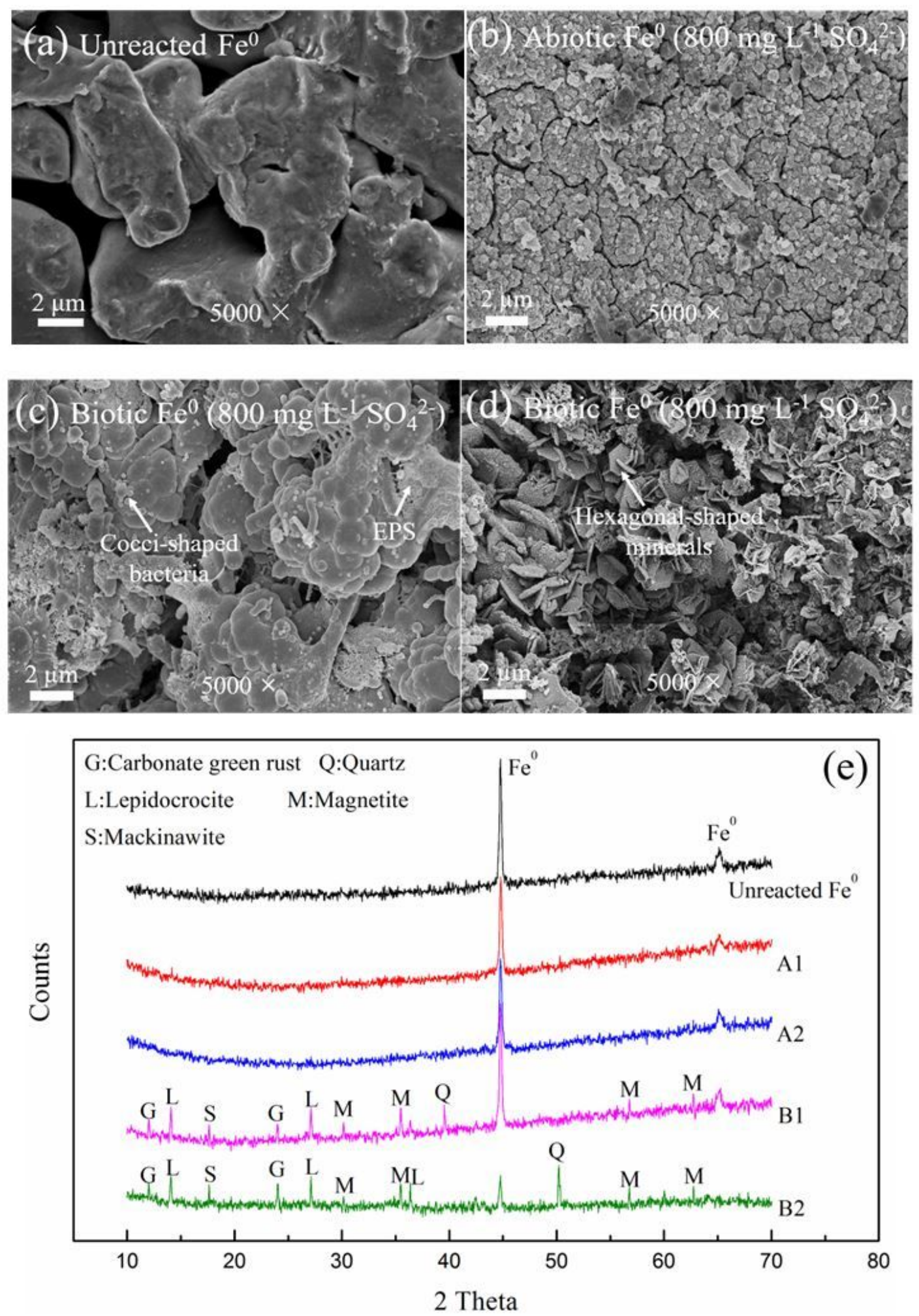

Figure 6

(a)-(d) SEM images of the $\mathrm{Fe}^{0}$ surface and corrosion products ((a) unreacted $\mathrm{Fe}^{0}$; (b) abiotic $\mathrm{Fe}^{0}$ collected from the abiotic $\mathrm{Fe}^{0}$ column under $800 \mathrm{mg} \mathrm{L}^{-1} \mathrm{SO}_{4}{ }^{2-}$; (c) and (d) were the microbial colonization and 
reactive minerals on the biotic $\mathrm{Fe}^{0}$ surface collected from the biotic $\mathrm{Fe}^{0}$ column under $800 \mathrm{mg} / \mathrm{L} \mathrm{SO}_{4}{ }^{2-}$ ); (e) XRD patterns of the iron coatings composed from the abiotic and biotic $\mathrm{Fe}^{0}$ (A1 and $\mathrm{B} 1$ stood for abiotic and biotic $\mathrm{Fe}^{0}$ coatings reacted at $100 \mathrm{mg} \mathrm{L}^{-1} \mathrm{SO}_{4}{ }^{2}$, respectively; $\mathrm{A} 2$ and $\mathrm{B} 2$ stood for abiotic and biotic $\mathrm{Fe}^{0}$ coatings responded at $800 \mathrm{mg} \mathrm{L}^{-1} \mathrm{SO}_{4}{ }^{2}$, respectively) 